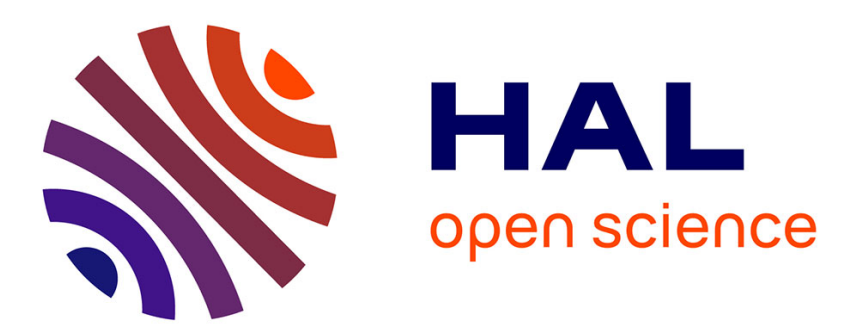

\title{
Impacts of stream acidification on litter breakdown: implications for assessing ecosystem functioning
}

Olivier Dangles, Mark O. Gessner, François Guérold, Eric Chauvet

\section{To cite this version:}

Olivier Dangles, Mark O. Gessner, François Guérold, Eric Chauvet. Impacts of stream acidification on litter breakdown: implications for assessing ecosystem functioning. Journal of Applied Ecology, 2004, vol. 41 ( $\mathrm{n}^{\circ} 2$ ), pp. 365-378. 10.1111/j.0021-8901.2004.00888.x . hal-01312782

\section{HAL Id: hal-01312782 \\ https://hal.science/hal-01312782}

Submitted on 9 May 2016

HAL is a multi-disciplinary open access archive for the deposit and dissemination of scientific research documents, whether they are published or not. The documents may come from teaching and research institutions in France or abroad, or from public or private research centers.
L'archive ouverte pluridisciplinaire HAL, est destinée au dépôt et à la diffusion de documents scientifiques de niveau recherche, publiés ou non, émanant des établissements d'enseignement et de recherche français ou étrangers, des laboratoires publics ou privés. 


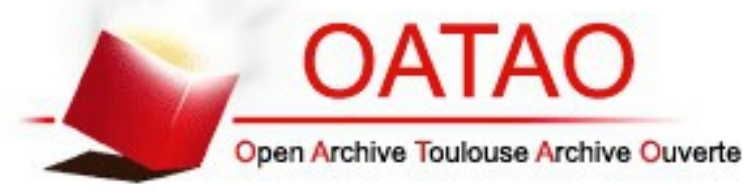

\section{Open Archive TOULOUSE Archive Ouverte (OATAO)}

OATAO is an open access repository that collects the work of Toulouse researchers and makes it freely available over the web where possible.

This is an author-deposited version published in : http://oatao.univ-toulouse.fr/ Eprints ID : 9641

To link to this article : DOI :10.1111/j.0021-8901.2004.00888.x URL : http://dx.doi.org/10.1111/j.0021-8901.2004.00888.x

To cite this version : Dangles, Olivier and Gessner, Mark O. and Guérold, François and Chauvet, Eric Impacts of stream acidification on litter breakdown: implications for assessing ecosystem functioning. (2004) Journal of Applied Ecology, vol. 41 ( $\left.{ }^{\circ} 2\right)$. pp. 365-378. ISSN 0021-8901

Any correspondance concerning this service should be sent to the repository administrator: staff-oatao@,listes-diff.inp-toulouse.fr 


\title{
Impacts of stream acidification on litter breakdown: implications for assessing ecosystem functioning
}

\author{
OLIVIER DANGLES*†, MARK O. GESSNER †, FRANÇOIS GUEROLD* and \\ ERIC CHAUVET§ \\ *Université de Metz, Laboratoire Biodiversité et Fonctionnement des Ecosystèmes, Rue du Général Délestraint, 57070 \\ Metz, France; †Institut de Recherche sur la Biologie de l'Insecte, UMR CNRS 6035, Faculté des Sciences et \\ Techniques, Université François Rabelais, 37200 Tours, France; $\$$ Department of Limnology, EAWAG, Limnological \\ Research Center, 6047 Kastanienbaum, Switzerland; and \$Laboratoire Dynamique de la Biodiversité, UMR 5172 \\ CNRS-Université Paul Sabatier, 29 rue Jeanne Marvig, 31055 Toulouse Cedex, France
}

\section{Summary}

1. Scientific understanding of acidification in aquatic ecosystems relies on effective assessment, which at present is mostly limited to chemical and sometimes structural biological variables. Effects on ecosystem functioning are, in contrast, largely neglected. Litter breakdown is a potentially useful, highly integrative and crucial process that could enhance such assessment programmes.

2. Breakdown rates of beech Fagus sylvatica leaves were determined in 25 woodland headwater streams along an acidification gradient in the Vosges Mountains, France. Additional data relating to micro-organisms (microbial respiration, fungal biomass and degree of conditioning measured as leaf palatability) and macroinvertebrates (shredder diversity, abundance and biomass) associated with decomposing leaves were collected to elucidate the mechanisms underlying leaf breakdown.

3. Breakdown rates varied more than 20 -fold between the most acidified and circumneutral sites $\left(k=0.0002-0.0055 \mathrm{day}^{-1}\right)$. Stream water alkalinity and total Al concentration together accounted for $88 \%$ of the variation in litter breakdown rates among streams. Microbial factors associated with decaying leaves, particularly microbial respiration, declined with increasing stream acidity and were significantly related to $\mathrm{Ca}^{2+}$ and total $\mathrm{Al}$ concentrations.

4. Total abundance, biomass and richness of leaf-shredding invertebrates associated with decomposing leaves were not related to stream acidity. However, the abundance and biomass of the amphipod Gammarus fossarum, an acid-sensitive and particularly efficient leaf-shredder, showed a strong positive relationship with leaf breakdown rate. Gammarus abundance and microbial respiration together accounted for $85 \%$ of the variation in litter breakdown rates among streams.

5. Synthesis and applications. These results indicate that leaf-litter breakdown responds strongly to stream acidification, with both microbial decomposers and invertebrate detritivores markedly affected. Measuring leaf breakdown rate may be developed into a simple, powerful and low-cost tool for assessing a critical component of ecosystem functioning. We advocate further investigation of this approach for the routine biomonitoring of freshwaters affected by, or recovering from, other anthropogenic stresses.

Key-words: bioassessment, environmental monitoring, fungi, leaf decomposition, leaf-shredding invertebrates, microbial respiration, water quality

Correspondence: Olivier Dangles, Institut de Recherche sur la Biologie de l'Insecte, UMR CNRS 6035, Faculté des Sciences et Techniques, Université François Rabelais, 37200 Tours, France (e-mail olivier.dangles@univ-tours.fr).

\section{Introduction}

Long-range atmospheric transport and subsequent deposition of acidifying substances has degraded surface waters in many areas of the world (Schindler 1988; Driscoll et al. 2001). Since the 1980s, rates of acidic 
deposition have decreased across North America and Europe following national and international abatement protocols (e.g. the Clean Air Act in the USA and the Convention on Long-Range Transboundary Air Pollution in Europe; Likens, Butker \& Buso 2001). However, both empirical results and dynamic modelling indicate that the expected recovery of alkalinity has not occurred in all areas where sulphate deposition has decreased (Stoddard et al. 1999). In addition, $\mathrm{Ca}^{2+}$ and other cations continue to be depleted in surface waters draining geologically sensitive areas, apparently as a result of the high rates of acidic deposition in the past and recent decreases in cation deposition (Lawrence et al. 1999; Stoddard et al. 1999). Further, the relative importance of elevated nitrogen deposition has recently increased in freshwater acidification (Sullivan et al. 1997; Lepori, Barbieri \& Ormerod 2003a,b). Thus, it has become clear that acidification impacts will continue to deteriorate aquatic ecosystems for decades (Driscoll et al. 2001), perhaps exacerbated by the effect of global warming (Schindler et al. 1996).

Sound understanding of acidification effects in ecosystems relies on effective assessment. Most assessment programmes currently in place are largely limited to atmosphere-water or surface-water chemistry, whereas effects on biological communities and whole ecosystems are now rarely analysed (Lancaster et al. 1996; Bradley \& Ormerod 2002). Episodic inputs of acidic rainwater, and especially meltwater, typically result in large temporal fluctuations in the chemical quality of acidsensitive waters. Consequently, large sampling efforts are needed to derive reliable information on the ecological effects of acidification from chemical measures alone. In contrast, biological variables integrate acidification effects through time, thus circumventing the problem of temporal variability in water chemistry (Lancaster et al. 1996). Benthic invertebrates have been used successfully to this effect (Otto \& Svensson 1983; Fjellheim \& Raddum 1990; Larsen et al. 1996), although some concern has been raised that differences among regions in species' tolerance limits may weaken the use of general indicator models (Hämäläinen \& Huttunen 1996).

Many goals in the conservation and restoration of aquatic ecosystems relate to ecosystem processes (Boon 2000). In addition to structural biological parameters (e.g. macroinvertebrate, fish and diatom community structure), it is desirable to determine which ecosystem processes respond to anthropogenic stresses, and which may be good indicators of functional ecosystem damage (Wallace, Grubaugh \& Whiles 1996; Gessner $\&$ Chauvet 2002). Functional traits of both plants and animals can indicate ecosystem functioning (Statzner et al. 2001; Hooper et al. 2002) but the extent to which modified community structure reflects altered ecosystem processes in streams is poorly known (Wallace \& Webster 1996). Assessment schemes targeted at ecosystem processes are few (Minshall 1996; Bunn \& Davies 2000; Gessner \& Chauvet 2002). This gap is a fundamental limitation of current ecosystem assessment, particularly in view of the American Clean Water Act (33 USC Section 1251 et seq.; http://www4.law.cornell. edu/uscode/33/1251.html) and the European Water Framework Directive (EU 2000; http://europa.eu.int/ comm/environment/water/water-framework/index_ en.html), which both draw explicit attention to the functional integrity of aquatic ecosystems.

Examples of potentially useful ecosystem processes in stream assessment include primary production, sediment and community respiration, nutrient transformations and leaf-litter breakdown (Minshall 1996; Giller \& Malmqvist 1998; Gessner \& Chauvet 2002). Because forested headwater streams receive a large proportion of their energy inputs from allochthonous leaf litter from riparian vegetation (Wallace et al. 1997, 1999), leaf breakdown plays a pivotal functional role (Webster \& Benfield 1986; Maltby 1996; Gessner, Chauvet \& Dobson 1999; Graça 2001). Consequently, litter breakdown is a key process for assessing the possible impact of acidification on stream ecosystem functioning (Maltby et al. 1995; Wallace, Grubaugh \& Whiles 1996; Bunn, Davies \& Mosisch 1999; Nelson 2000; Niyogi, Lewis \& McKnight 2001; Gessner \& Chauvet 2002). Effects of stream acidification on leaf breakdown have been suggested, but so far from only a small number of sites (Burton, Stanford \& Allan 1985; Chamier 1987; Groom \& Hildrew 1989; Mulholland et al. 1992; Griffith \& Perry 1993; Dangles \& Guérold 1998; cf. Niyogi, Lewis \& McKnight 2001).

The main objective of the present study was to determine whether leaf breakdown was systematically related to acidification across a range of forest streams. Leaf breakdown was studied along an acidification gradient at 25 sites differing in $\mathrm{pH}$, alkalinity, $\mathrm{Ca}^{2+}$ and total Al concentration. A range of biological variables relating to the microbial and macroinvertebrate communities associated with decomposing leaves was analysed. Finally, interannual variability in litter breakdown was examined by repeating the experiment in three consecutive years in seven selected streams.

\section{Methods}

\section{STUDY SITES}

The Vosges Mountains, in north-eastern France, are sensitive to acidification due to the prevalence of quartzenriched sandstone and granite bedrock (Dambrine et al. 1995). Atmospheric deposition during the last few decades (up to $1.0 \mathrm{kmoL} \mathrm{ha}^{-1}$ year $^{-1}$ of $\mathrm{H}^{+}$and $15 \mathrm{~kg} \mathrm{ha}^{-1}$ year ${ }^{-1}$ of $\mathrm{SO}_{4}^{2-}$ ) has resulted in surface water acidification (Probst et al. 1990a; Dambrine et al. 1998), particularly in catchments covered by coniferous forests (Probst et al. 1990b). An important characteristic of the area is that small-scale differences in mineral composition of the underlying bedrock produce marked differences in buffering capacity, ion content and acidification, sometimes even between adjacent streams. 


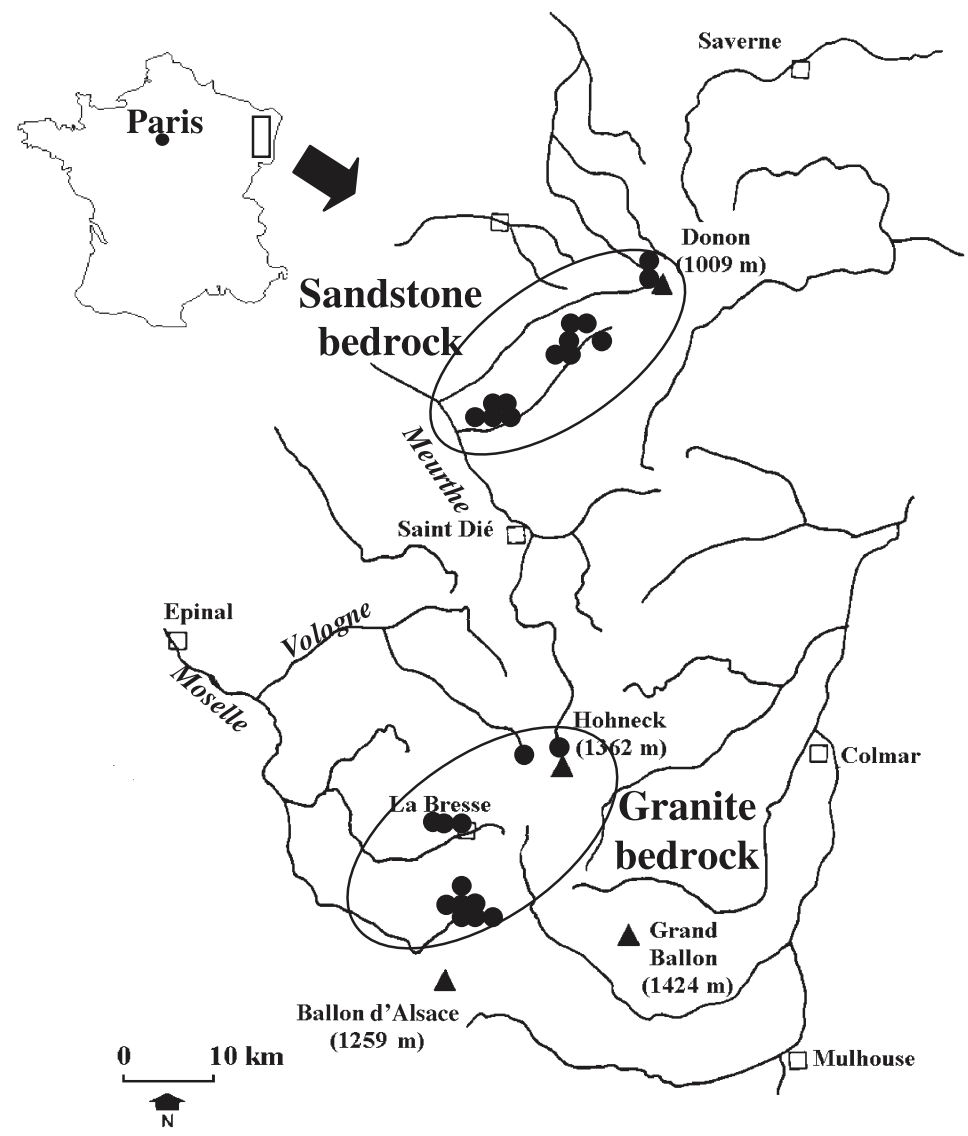

Fig. 1. Location of the study sites in the Vosges Mountains, north-eastern France.

Twenty-five first- and second-order streams varying in acidification status were selected (Table 1 and Fig. 1) based on previous data from 394 streams in the region (Guérold et al. 1997). Vegetation in the selected catchments was dominated by silver fir Abies alba Mill., Norway spruce Picea abies L. and beech Fagus sylvatica L. Beech is by far the most common deciduous tree species adjacent to streams and provides almost all leaf-litter inputs. All study sites were located upstream of direct influences such as housing, farming and industrial activities (except selective logging), and showed similar morphology and hydrology.

\section{WATER CHEMISTRY}

Temperature and $\mathrm{pH}$ were measured monthly from December 1998 to November 1999 in situ at all sites using a glass electrode for solutions of low ionic strength (combined $\mathrm{pH}$ electrode for deionized water, S7 head; Bioblock Scientific, Illkirch, France). Field and subsequent laboratory measurements of $\mathrm{pH}$ produced similar results. Water samples for chemical analyses were also collected monthly and returned to the laboratory in polyethylene bottles. Alkalinity was determined by Gran (1952) titration to $\mathrm{pH} 3 \cdot 8$. Conductivity was measured with a Metrohm Herisau Conductometer E518 (Herisau, Switzerland) at $20^{\circ} \mathrm{C}$. Concentrations of $\mathrm{Ca}^{2+}, \mathrm{Mg}^{2+}, \mathrm{Na}^{+}, \mathrm{K}^{+}$and total $\mathrm{Al}$ (after acidification with $\mathrm{HNO}_{3}$ ) were determined by atomic absorption spectrophotometry (Aanalyst 100; Perkin Elmer), and concentrations of $\mathrm{Cl}^{-}, \mathrm{SO}_{4}^{2-}$ and $\mathrm{NO}^{3-}$ by ion chromatography (Dionex 1500 i with a AS 4 A SC column; Sunnyvale, USA).

\section{LEAF BREAKDOWN}

Beech leaves were collected from trees just before abscission in the autumn of 1998 . Three grams of airdried leaves were enclosed in 5-mm plastic mesh bags $(15 \times 10 \mathrm{~cm})$, eight of which were submerged at each site on 10 December 1998. Air-drying can entail rapid initial mass loss of leaves through leaching (Gessner \& Schwoerbel 1989), but this effect is small for beech leaves (4-5\%; Dangles \& Guérold 2001a) and was not specifically accounted for. The bags were secured to the bank with plastic-coated wire and tied to boulders on the stream bed. Four replicate bags were recovered after 100 and 200 days and returned to the laboratory. The leaves were rinsed individually with water from the corresponding stream to remove fine particulate matter and invertebrates. Thirty 2-cm diameter discs were cut from the leaves of three bags avoiding the central veins. The remaining leaf material was air-dried to constant mass and subsamples ashed for $4 \mathrm{~h}$ at $550{ }^{\circ} \mathrm{C}$ to relate air dry mass to ash-free dry mass (AFDM).

The same protocol was used to determine the breakdown of beech leaves at a smaller set of seven sites (GS, WA, RR, BR, MR, HR and LM) in the winter and 
Table 1. Characteristics of the study sites. Mean $\mathrm{pH}$ values $(n=7-11)$ are from Guérold et al. (1997)

\begin{tabular}{|c|c|c|c|c|c|c|c|c|c|c|}
\hline Stream & Site & Grid reference & $\begin{array}{l}\text { Bedrock } \\
\text { geology }\end{array}$ & $\begin{array}{l}\text { Mean } \\
\mathrm{pH}\end{array}$ & $\begin{array}{l}\text { Stream } \\
\text { order }\end{array}$ & $\begin{array}{l}\text { Altitude } \\
\text { (m a.s.l.) }\end{array}$ & $\begin{array}{l}\text { Distance from } \\
\text { source }(\mathrm{m})\end{array}$ & $\begin{array}{l}\text { Channel } \\
\text { width (m) }\end{array}$ & $\begin{array}{l}\text { Channel } \\
\text { slope (\%o) }\end{array}$ & Riparian vegetation \\
\hline Gentil Sapin & GS & $48^{\circ} 02^{\prime} 17^{\prime \prime} \mathrm{N} 7^{\circ} 05^{\prime} 23^{\prime \prime} \mathrm{E}$ & Sandstone & $4 \cdot 49$ & 1 & 510 & 3100 & $2 \cdot 30$ & $10 \cdot 0$ & Abies alba, Fagus sylvatica, Picea abies, Acer pseudoplatanus \\
\hline Rabodeau & $\mathrm{RB}$ & $48^{\circ} 27^{\prime} 35^{\prime \prime} \mathrm{N} 7^{\circ} 03^{\prime} 21^{\prime \prime} \mathrm{E}$ & Sandstone & $4 \cdot 66$ & 2 & 520 & 5000 & $4 \cdot 90$ & $16 \cdot 0$ & A. alba, F. sylvatica, P. abies, A. pseudoplatanus \\
\hline Wassongoute & WA & $47^{\circ} 58^{\prime} 40^{\prime \prime} \mathrm{N} 6^{\circ} 53^{\prime} 22^{\prime \prime} \mathrm{E}$ & Granite & $4 \cdot 71$ & 1 & 690 & 2600 & $2 \cdot 00$ & $13 \cdot 8$ & F. sylvatica, A. alba \\
\hline Bas-Rupts & $\mathrm{BR}$ & $48^{\circ} 02^{\prime} 17^{\prime \prime} \mathrm{N} 6^{\circ} 52^{\prime} 54^{\prime \prime} \mathrm{E}$ & Granite & $4 \cdot 81$ & 1 & 845 & 900 & $1 \cdot 40$ & $20 \cdot 0$ & A. alba, F. sylvatica \\
\hline Rouge-Rupt & $\mathrm{RR}$ & $47^{\circ} 58^{\prime} 28^{\prime \prime} \mathrm{N} 6^{\circ} 53^{\prime} 19^{\prime \prime} \mathrm{E}$ & Granite & $4 \cdot 88$ & 2 & 675 & 4700 & $5 \cdot 50$ & $8 \cdot 4$ & F. sylvatica, A. alba \\
\hline Malfosse & MA & $48^{\circ} 25^{\prime} 18^{\prime \prime} \mathrm{N} 6^{\circ} 56^{\prime} 07^{\prime \prime} \mathrm{E}$ & Sandstone & $4 \cdot 96$ & 2 & 350 & 3400 & $5 \cdot 00$ & $8 \cdot 0$ & F. sylvatica, $P$. abies, $A$. alba \\
\hline Longfoigneux & LG & $47^{\circ} 58^{\prime} 15^{\prime \prime} \mathrm{N} 6^{\circ} 52^{\prime} 17^{\prime \prime} \mathrm{E}$ & Granite & $4 \cdot 99$ & 1 & 600 & 1180 & $1 \cdot 30$ & $22 \cdot 0$ & F. sylvatica, A. alba \\
\hline Ventron & VE & $47^{\circ} 58^{\prime} 18^{\prime \prime} \mathrm{N} 6^{\circ} 55^{\prime} 22^{\prime \prime} \mathrm{E}$ & Granite & $5 \cdot 01$ & 1 & 820 & 2500 & $1 \cdot 50$ & $10 \cdot 0$ & F. sylvatica, A. alba \\
\hline Repafosse & $\mathrm{RE}$ & $48^{\circ} 25^{\prime} 31^{\prime \prime} \mathrm{N} 6^{\circ} 57^{\prime} 16^{\prime \prime} \mathrm{E}$ & Sandstone & $5 \cdot 02$ & 1 & 405 & 1800 & $2 \cdot 10$ & $6 \cdot 0$ & F. sylvatica, $P$ abies, $A$. alba \\
\hline Ravines & $\mathrm{RV}$ & $48^{\circ} 25^{\prime} 47^{\prime \prime} \mathrm{N} 6^{\circ} 57^{\prime} 08^{\prime \prime} \mathrm{E}$ & Sandstone & $5 \cdot 04$ & 1 & 410 & 3300 & $2 \cdot 50$ & $6 \cdot 0$ & F. sylvatica, P. abies, A. alba \\
\hline Madeleine & MD & $48^{\circ} 27^{\prime} 26^{\prime \prime} \mathrm{N} 7^{\circ} 07^{\prime} 50^{\prime \prime} \mathrm{E}$ & Sandstone & $5 \cdot 18$ & 1 & 510 & 2400 & $1 \cdot 90$ & $16 \cdot 0$ & F. sylvatica, P. abies, A. alba \\
\hline Echarges & $\mathrm{EC}$ & $47^{\circ} 58^{\prime} 39^{\prime \prime} \mathrm{N} 6^{\circ} 54^{\prime} 29^{\prime \prime} \mathrm{E}$ & Granite & $5 \cdot 22$ & 1 & 730 & 2000 & $2 \cdot 30$ & $14 \cdot 0$ & F. sylvatica, A. alba \\
\hline Chevrosgoutte & $\mathrm{CH}$ & $48^{\circ} 24^{\prime} 21^{\prime \prime} \mathrm{N} 6^{\circ} 55^{\prime} 01^{\prime \prime} \mathrm{E}$ & Sandstone & $5 \cdot 31$ & 1 & 390 & 1500 & $1 \cdot 20$ & $28 \cdot 0$ & F. sylvatica, P. abies, A. alba \\
\hline Moyens-Rupts & MR & $48^{\circ} 02^{\prime} 24^{\prime \prime} \mathrm{N} 6^{\circ} 52^{\prime} 55^{\prime \prime} \mathrm{E}$ & Granite & 5.76 & 1 & 850 & 1000 & $1 \cdot 60$ & $24 \cdot 0$ & A. alba, F. sylvatica \\
\hline Grands-Clos & GC & $47^{\circ} 58^{\prime} 47^{\prime \prime} \mathrm{N} 6^{\circ} 52^{\prime} 35^{\prime \prime} \mathrm{E}$ & Granite & $5 \cdot 77$ & 1 & 650 & 1750 & $2 \cdot 30$ & $21 \cdot 1$ & F. sylvatica, A. alba \\
\hline La Maix & LM1 & $48^{\circ} 29^{\prime} 03^{\prime \prime} \mathrm{N} 7^{\circ} 05^{\prime} 40^{\prime \prime} \mathrm{E}$ & Sandstone & $5 \cdot 85$ & 1 & 516 & 2200 & $2 \cdot 00$ & $8 \cdot 0$ & F. sylvatica, A. alba, Alnus glutinosa \\
\hline Hauts-Rupts & HR & $48^{\circ} 02^{\prime} 41^{\prime \prime} \mathrm{N} 6^{\circ} 53^{\prime} 37^{\prime \prime} \mathrm{E}$ & Granite & $6 \cdot 24$ & 2 & 855 & 2550 & $3 \cdot 30$ & $13 \cdot 9$ & A. alba, F. sylvatica \\
\hline La Maix & LM3 & $48^{\circ} 29^{\prime} 34^{\prime \prime} \mathrm{N} 7^{\circ} 03^{\prime} 36^{\prime \prime} \mathrm{E}$ & Sandstone & $6 \cdot 38$ & 1 & 514 & 30 & $1 \cdot 30$ & $3 \cdot 0$ & F. sylvatica, A. alba, A. glutinosa \\
\hline La Maix & LM2 & $48^{\circ} 28^{\prime} 06^{\prime \prime} \mathrm{N} 7^{\circ} 05^{\prime} 07^{\prime \prime} \mathrm{E}$ & Sandstone & $6 \cdot 44$ & 2 & 512 & 2250 & $2 \cdot 00$ & $8 \cdot 0$ & F. sylvatica, A. alba, A. glutinosa \\
\hline Tihay & TI & $47^{\circ} 58^{\prime} 50^{\prime \prime} \mathrm{N} 6^{\circ} 52^{\prime} 32^{\prime \prime} \mathrm{E}$ & Granite & $6 \cdot 47$ & 1 & 660 & 1250 & $1 \cdot 80$ & $20 \cdot 0$ & A. alba, F. sylvatica, pasture \\
\hline Meurthe & ME & $48^{\circ} 04^{\prime} 50^{\prime \prime} \mathrm{N} 7^{\circ} 00^{\prime} 52^{\prime \prime} \mathrm{E}$ & Granite & $6 \cdot 48$ & 1 & 825 & 3300 & $2 \cdot 90$ & $6 \cdot 8$ & F. sylvatica, $A$. alba, pasture \\
\hline Vologne & VO & $48^{\circ} 03^{\prime} 17^{\prime \prime} \mathrm{N} 6^{\circ} 59^{\prime} 36^{\prime \prime} \mathrm{E}$ & Granite & $6 \cdot 60$ & 1 & 810 & 2100 & $3 \cdot 10$ & $19 \cdot 5$ & F. sylvatica, A. alba \\
\hline Plaine & PL & $48^{\circ} 31^{\prime} 39^{\prime \prime} \mathrm{N} 7^{\circ} 08^{\prime} 24^{\prime \prime} \mathrm{E}$ & Sandstone & $6 \cdot 94$ & 2 & 490 & 4900 & $4 \cdot 90$ & $3 \cdot 3$ & F. sylvatica, $P$. abies, $A$. alba, A. glutinosa \\
\hline Truite & $\mathrm{TR}$ & $48^{\circ} 28^{\prime} 08^{\prime \prime} \mathrm{N} 7^{\circ} 08^{\prime} 47^{\prime \prime} \mathrm{E}$ & Sandstone & $7 \cdot 05$ & 1 & 500 & 2500 & $2 \cdot 10$ & $12 \cdot 0$ & F. sylvatica, P. abies, A. alba \\
\hline La Maix & LM4 & $48^{\circ} 29^{\prime} 08^{\prime \prime} \mathrm{N} 7^{\circ} 05^{\prime} 16^{\prime \prime} \mathrm{E}$ & Sandstone & $7 \cdot 26$ & 2 & 410 & 4900 & $2 \cdot 20$ & $9 \cdot 5$ & F. sylvatica, $P$. abies, $A$. alba, A. glutinosa \\
\hline
\end{tabular}


spring of 1997-98 and 1999-2000, to test for interannual variability of leaf breakdown rates. These selected sites represented the full range of $\mathrm{pH}$ values between 4.5 and $7 \cdot 3$. As in 1998-99, leaves were placed in the streams in December and retrieved after 100 and 200 days.

\section{MICROBIAL RESPIRATION}

Microbial respiration was measured on leaves retrieved after 100 days. Three replicate sets of 30 leaf discs each were placed in 10-mL flasks filled with water collected at the same time in the corresponding site (base flow conditions) and incubated with stirring. Temperature was maintained at $4 \pm 1{ }^{\circ} \mathrm{C}$ during incubations, close to ambient water temperature for all streams in early March. An additional flask containing only stream water was used as a control. Four oxygen probes (CellOx 325, Woburn, USA) connected to an oxymeter (WTW Multiline P4, Woburn, USA) measured oxygen concentrations every $16 \mathrm{~s}$ for $3-5 \mathrm{~h}$, depending on rates of oxygen decline. Respiration rates were calculated from slopes of oxygen concentrations regressed against time during periods of linear decrease, and are expressed as $\mathrm{mg} \mathrm{O}_{2}$ g leaf $\mathrm{AFDM}^{-1}$ day $^{-1}$.

\section{FUNGAL BIOMASS}

Ergosterol was used as an indicator of fungal biomass (Gessner \& Newell 2002). Three replicate sets of 30 discs from the leaves retrieved after 100 days were blotted dry and preserved in pure methanol. Ergosterol was extracted by 30 min refluxing in alcoholic base, purified by solidphase extraction and quantified by high-pressure liquid chromatography (Gessner \& Schmitt 1996).

\section{LEAF PALATABILITY}

The palatability of leaves to detritivores was defined as leaf consumption by the shredding amphipod Gammarus fossarum (Koch), an abundant species in most circumneutral streams in the study area. Animals were collected with a hand net from site LM4. They were acclimated to laboratory conditions $\left(8 \pm 1^{\circ} \mathrm{C}\right.$, natural 12 -h daylight period, water from LM4) for $24 \mathrm{~h}$. Ten gammarids and the 30 leaf discs used previously for measuring microbial respiration were then placed in plastic cylinders (diameter $6 \mathrm{~cm}$, height $5 \mathrm{~cm}$ ) covered with a $0 \cdot 3-\mathrm{mm}$ mesh screen on both ends. The initial AFDM of the leaf material was determined on five additional discs cut from the leaves from each bag. Three replicate cylinders with animals, each corresponding to a different leaf bag, and one control without animals were used for each of the 25 streams. All cylinders were placed together in an aquarium filled with filtered water from LM4 and aerated with an aquarium pump. After 6 days the animals and the remaining leaf fragments were removed, ovendried $\left(105^{\circ} \mathrm{C}, 24 \mathrm{~h}\right)$ and ashed $\left(550^{\circ} \mathrm{C}, 4 \mathrm{~h}\right)$. Consumed leaf mass was calculated as the difference between the initial and remaining AFDM.

\section{SHREDDER ABUNDANCE AND BIOMASS}

Invertebrate shredders (as classified by Tachet et al. 2000) from the leaf bags were preserved in $70 \%$ ethanol, identified to the lowest practicable taxonomic level (mostly species or genus) and counted. Biomass was determined by weighing dried individuals $\left(105^{\circ} \mathrm{C}, 24 \mathrm{~h}\right)$ to the nearest $0.01 \mathrm{mg}$.

\section{DATA ANALYSIS}

Principal components analysis (PCA) was carried out using the correlation matrix of $\log (x+1)$ transformed data to ordinate streams with respect to all physicochemical variables. Calculations and graphics were made using ADE 4. 0 software, a data analysis package designed for multivariate statistics (Thioulouse et al. 1997; http:// pbil.univ-lyon1.fr/ADE-4).

Leaf breakdown rates $(k)$ were estimated by fitting the AFDM data to the exponential model, $Y_{t}=Y_{0} \mathrm{e}^{-k t}$, where $Y_{t}$ is the AFDM remaining at time ${ }_{t}$ in days, and $Y_{0}$ the AFDM at the beginning of the experiment (Petersen \& Cummins 1974).

Partial least-squares (PLS) regression (Abdi 2003) was used to construct a descriptive model predicting litter breakdown from water chemistry. PLS regression analysis can be viewed as a generalized multiple regression that copes with collinearity, thus adequately taking into account the auto-correlations among the physicochemical variables (e.g. pH, alkalinity, $\mathrm{Ca}^{2+}$ and $\mathrm{Mg}^{2+}$ concentrations). The generated variable importance in the projection (VIP) values reflect the importance of a given variable (e.g. mean $\mathrm{pH}$, minimum alkalinity, minimum total $\mathrm{Al}$ concentration) in the model with respect to both the breakdown rate and the projected water chemical variables. PLS regressions were calculated with the software SIMCA (version 7·0; Umetri AB, Umeå, Sweden). Mean, median and stress values based on the 11 monthly measurements were used as input variables. Stress values refer to either the lowest (e.g. pH, alkalinity, $\mathrm{Ca}^{2+}$ concentration) or highest (e.g. total Al concentration) value in the data set, depending on whether high or low values were considered stressful.

Multiple linear regressions were used to detect effects of the three major stresses associated with acidified waters (i.e. low $\mathrm{pH}$, low $\mathrm{Ca}^{2+}$ and high total $\mathrm{Al}$ concentrations) on eight leaf-associated biological variables: microbial respiration; fungal biomass; leaf palatability; abundance, biomass and richness of shredder taxa; and abundance and biomass of Gammarus. Simple linear regressions were computed using each of these biological variables as a predictor of leaf breakdown rate. Further, a PLS analysis followed by a stepwise multiple linear regression was conducted using all significant $(P<0.05)$ predictors from the simple linear regressions on the response variable; the PLS analysis was carried out first to select variables for the subsequent stepwise regressions that showed no auto-correlation. For these analyses, we considered breakdown rates calculated for the first 100 days only. 
Finally, a two-way analysis of variance (ANOVA) was used on log-transformed data from the seven streams examined in three consecutive years to test for effects of 'year' and 'site' on leaf breakdown rate.

\section{Results}

\section{WATER CHEMISTRY}

The first axis of the PCA of physical and water chemical data was defined primarily by four key variables related to stream water acidity: $\mathrm{pH}$, alkalinity and concentrations of $\mathrm{Ca}^{2+}$ and $\mathrm{Mg}^{2+}$ (Fig. 2). It explained $62 \%$ of the total variance. An additional $23 \%$ of the variance was explained by the second axis, which separated the streams in catchments underlain by sandstone vs. granite bedrock. Streams in granitic catchments (e.g. LM1 and GC) were characterized by lower ion contents at a given $\mathrm{pH}$, including lower concentration of sulphates but also lower concentrations of total $\mathrm{Al}$, compared with streams draining sandstone. The dispersion of individual samples at a given site indicated seasonal and event-driven chemical changes. For example, at the sites ML, MD, CH and LM1, pH dropped by c. 1.8 units during a prolonged period of snow-melt in March 1999. Other streams (e.g. GS and RB), however, were permanently acidic, and water chemistry of the relatively wellbuffered sites (LM4, LM3 and ME) also varied little during the study.

\section{LEAF BREAKDOWN RATES}

Leaf breakdown rates ranged from $0.0002 \mathrm{day}^{-1}$ at the most acidic site (GS) to $0.0055 \mathrm{day}^{-1}$ at the circumneutral site LM4. Alkalinity was the single best physicochemical predictor of breakdown rate, as inferred from the

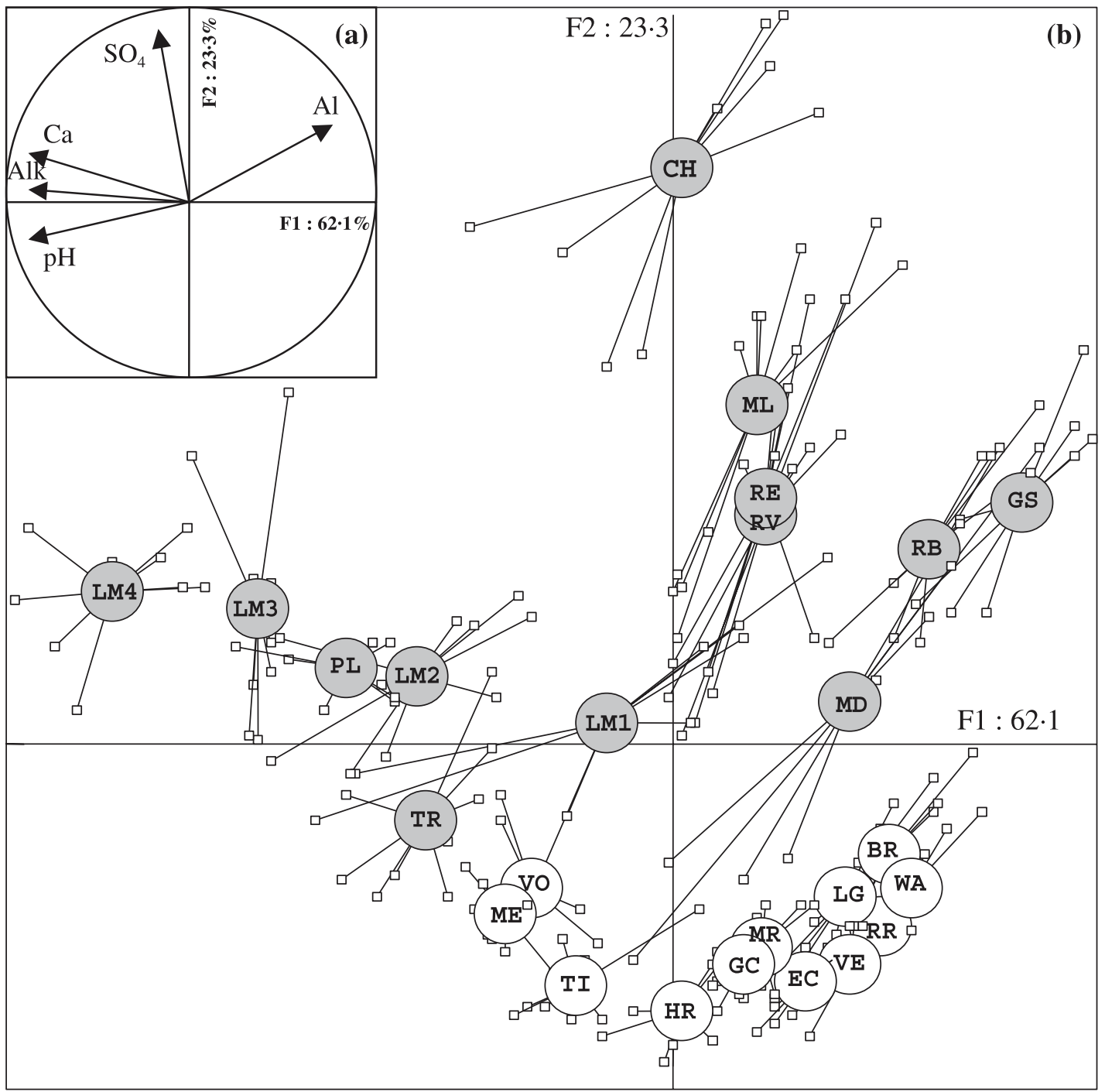

Fig. 2. PCA of physicochemical variables determined monthly between December 1998 and December 1999 at 25 stream sites in the Vosges Mountains. (a) Position of variables on the F1 $\times$ F2 plane. (b) Ordination of the 25 selected sites on the F1 $\times$ F 2 plane. Small squares represent the sample position at each sampling date. Open circles denote the weighted average of all samples taken from a given stream. Grey circles, streams draining sandstone bedrock; open circles, streams draining granitic bedrock. Lines link samples to their weighted average. 


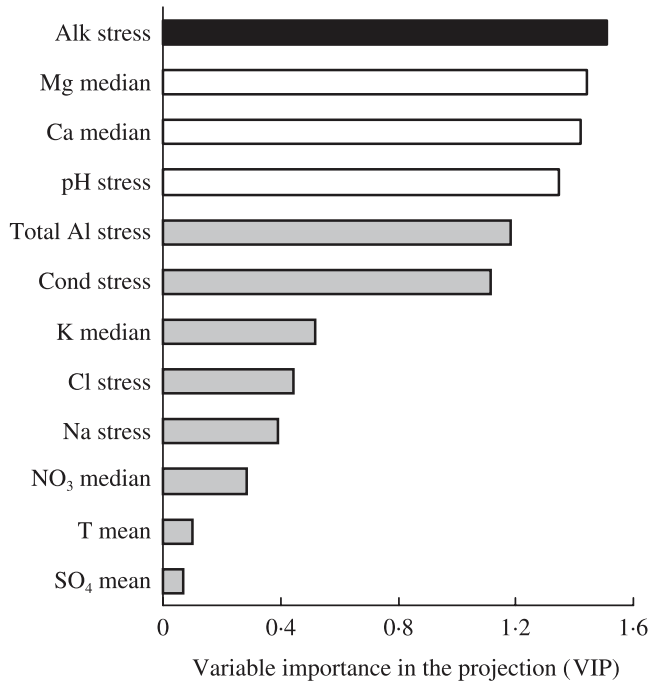

Fig. 3. Results of PLS regression analysis showing the importance of different physicochemical variables in the projection. Because VIP values of mean, median and stress values for each parameter were very similar, only the highest of these values is presented for each physicochemical variable. The black bar represents the most important variable (MIV); white bars show variables significantly correlated with MIV (d.f. $=23, r^{2}>0 \cdot 50, P<0 \cdot 05$, Pearson rank test); grey bars show parameters not significantly correlated with MIV. Alk, alkalinity; Cond, conductivity; $\mathrm{T}$, temperature.

highest VIP (1.47) assigned to alkalinity in the PLS regression analysis (Fig. 3). Stream $\mathrm{pH}$ and concentrations of $\mathrm{Ca}^{2+}$ and $\mathrm{Mg}^{2+}$ were significantly correlated with alkalinity $(P<0 \cdot 05)$, whereas total Al concentration $(\mathrm{VIP}=1 \cdot 18)$ was $\operatorname{not}(P=0 \cdot 21)$. Combining alkalinity and $\mathrm{Al}$ concentration in a single predictor, $\log (1+$ alkalinity $_{\text {stress }} /$ total $\mathrm{Al}_{\text {stress }}$ ), improved the prediction of leaf breakdown rate (VIP $=1 \cdot 60)$. As a result, leaf breakdown rate showed a strong positive relation with this ratio, irrespective of whether data from streams with zero alkalinity were included in the regression analysis (Fig. 4) or excluded $(y=0 \cdot 0017 x+0 \cdot 0007$, $\left.r^{2}=0.78\right)$. Leaf breakdown rates $(P>0.88)$ were not significantly related to physical variables such as channel width, slope and depth, distance from source and altitude. Similarly, the influence of discharge was likely to be insignificant because variations across streams were small (about 15 and $30 \mathrm{~L} \mathrm{~s}^{-1}$ at baseflow in first-and second-order, respectively).

\section{BIOLOGICAL FACTORS ASSOCIATED WITH DECAYING LEAVES}

Multiple linear regression analysis showed that five out of eight biological variables associated with decaying leaves were significantly predicted by $\mathrm{pH}$, concentrations of $\mathrm{Ca}^{2+}$ or total $\mathrm{Al}$ (Table 2). In no case was the addition of a second variable significant. The highest coefficients of determination were between ergosterol content and $\mathrm{pH}\left(r^{2}=0 \cdot 38\right)$, microbial respiration and total $\mathrm{Al}\left(r^{2}=0.60\right)$, leaf palatability and $\mathrm{pH}\left(r^{2}=0.62\right)$ and Gammarus abundance, biomass and $\mathrm{Ca}^{2+}$ concentration $\left(r^{2}=0.48\right.$ and $r^{2}=0.52$, respectively). Nonlinear models did not generally improve relationships.

The number and biomass of Gammarus associated with decaying leaves were more strongly related to leaf breakdown rate for each leaf pack than microbial variables (Fig. 5). Among the latter, leaf breakdown rate was more closely related to microbial respiration than to fungal biomass and leaf palatability. This relationship was positive, although several sites had high rates of microbial respiration but low rates of litter breakdown. Total shredder density and biomass were weakly correlated with leaf breakdown rate, as was shredder richness.

The six significant predictors from the single linear regressions (fungal biomass, microbial respiration, leaf palatability, shredder abundance, Gammarus abundance and biomass) were used in a PLS analysis followed by a stepwise multiple regression. Two significant predictors,

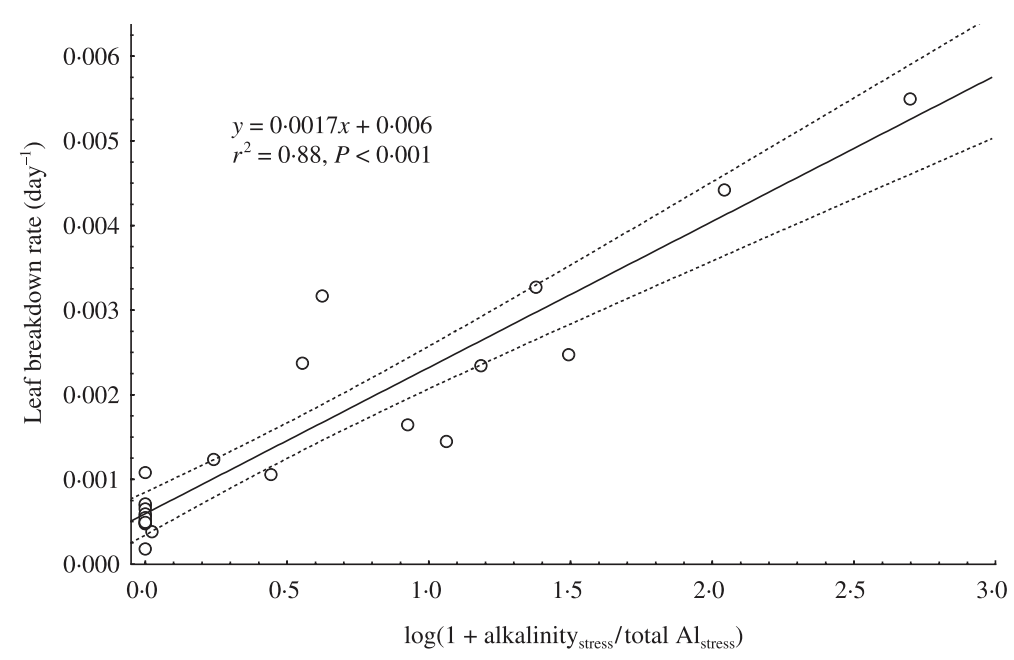

Fig. 4. Regression of leaf breakdown rate vs. $\log \left(1+\right.$ alkalinity $_{\text {stress }} /$ total $\left.\mathrm{Al}_{\text {stress }}\right)$. The dashed lines represent $95 \%$ confidence limits of the regression. 
Table 2. Multiple linear regression analysis of various biological variables associated with decaying leaves after 100 days of exposure against the three major stress factors $\left(\mathrm{pH}\right.$, calcium $\left(\mathrm{Ca}^{2+}\right)$, aluminium $\left.(\mathrm{Al})\right]$ in acidified water (mean, median and stress values of $\mathrm{pH}, \mathrm{Ca}^{2+}$ and total $\mathrm{Al}$ ) at the 25 study sites. Overall $r^{2}$ and $P$-values are based on multiple regressions with mean, median and stress values of $\mathrm{pH}, \mathrm{Ca}^{2+}$ and $\mathrm{Al}$. Only the two variables providing the best univariate regressions are shown

\begin{tabular}{|c|c|c|c|c|c|}
\hline Dependent variable & Overall $r^{2}$ & Overall $P$-value & Independent variable & Regression coefficient & $P$-value \\
\hline \multirow[t]{2}{*}{ Ergosterol content } & \multirow[t]{2}{*}{$0 \cdot 38$} & \multirow[t]{2}{*}{$0 \cdot 006$} & pH (stress) & $0 \cdot 61$ & $0 \cdot 001$ \\
\hline & & & $\mathrm{Ca}^{2+}$ (median) & $0 \cdot 53$ & $0 \cdot 007$ \\
\hline \multirow[t]{2}{*}{ Microbial respiration } & \multirow[t]{2}{*}{$0 \cdot 60$} & \multirow[t]{2}{*}{$<0.001$} & Total Al (median) & -0.73 & $<0 \cdot 001$ \\
\hline & & & pH (stress) & $0 \cdot 70$ & $<0.001$ \\
\hline \multirow[t]{2}{*}{ Leaf palatability } & \multirow[t]{2}{*}{$0 \cdot 62$} & \multirow[t]{2}{*}{$<0 \cdot 001$} & pH (median) & $0 \cdot 76$ & $<0.001$ \\
\hline & & & $\mathrm{Al}$ (mean) & $-0 \cdot 52$ & $0 \cdot 008$ \\
\hline \multirow[t]{2}{*}{ Shredder richness } & \multirow[t]{2}{*}{$0 \cdot 13$} & \multirow[t]{2}{*}{$0 \cdot 213$} & $\mathrm{Ca}^{2+}$ (median) & $-0 \cdot 29$ & $0 \cdot 154$ \\
\hline & & & pH (median) & $-0 \cdot 08$ & $0 \cdot 692$ \\
\hline \multirow[t]{2}{*}{ Shredder abundance } & \multirow[t]{2}{*}{$0 \cdot 10$} & \multirow[t]{2}{*}{$0 \cdot 310$} & $\mathrm{pH}$ (stress) & $0 \cdot 01$ & $0 \cdot 961$ \\
\hline & & & Total Al (mean) & $0 \cdot 10$ & $0 \cdot 624$ \\
\hline \multirow[t]{2}{*}{ Shredder biomass } & \multirow[t]{2}{*}{$0 \cdot 17$} & \multirow[t]{2}{*}{$0 \cdot 125$} & pH (mean) & $0 \cdot 30$ & $0 \cdot 144$ \\
\hline & & & $\mathrm{Ca}^{2+}$ (median) & $0 \cdot 06$ & $0 \cdot 757$ \\
\hline \multirow[t]{2}{*}{ G. fossarum abundance } & \multirow[t]{2}{*}{$0 \cdot 48$} & \multirow[t]{2}{*}{$0 \cdot 001$} & $\mathrm{Ca}^{2+}($ mean $)$ & $0 \cdot 68$ & $<0 \cdot 001$ \\
\hline & & & pH (stress) & $0 \cdot 62$ & $0 \cdot 001$ \\
\hline \multirow[t]{2}{*}{ G. fossarum biomass } & \multirow[t]{2}{*}{$0 \cdot 52$} & \multirow[t]{2}{*}{$<0 \cdot 001$} & $\mathrm{Ca}^{2+}$ (median) & $0 \cdot 70$ & $<0.001$ \\
\hline & & & pH (stress) & 0.68 & $<0.001$ \\
\hline
\end{tabular}

Gammarus abundance (VIP $=1 \cdot 37)$ and microbial respiration (VIP $=0 \cdot 89)$, emerged in the final regression model:

leaf breakdown rate $\left(\right.$ day $\left.^{-1}\right)=-1.5+0.65 \times$ Gammarus abundance (individuals per bag) $+85 \times$ microbial respiration $\left(\mathrm{mg} \mathrm{O}_{2} \mathrm{~g} \mathrm{AFDM}^{-1} \mathrm{day}^{-1}\right)$.

This model explained $84.6 \%$ of the variation in leaf breakdown rate, of which Gammarus abundance explained $70 \cdot 1 \%$ and microbial respiration the remaining $14.5 \%$. None of the variables added to Gammarus abundance and microbial respiration was significant, and a multiple regression including all six variables explained only an additional $4.7 \%$ of variation in leaf breakdown rate.

\section{AMONG-YEAR VARIABILITY OF LEAF BREAKDOWN}

There were significant differences in breakdown rates of beech leaves among the 3 study years ( Fig. 6; two-way ANOVA, $\left.F_{6,2}=25 \cdot 6, P<0 \cdot 001\right)$. This temporal variability was especially pronounced in the circumneutral streams, because of much lower breakdown rates in 1998-99. Qualitatively, however, the overall response pattern was constant among years. The only exception was in the changed rank order among the four acid streams during 1998-99, reflected in the significant interaction between stream and year on leaf breakdown rates (two-way ANOVA, $F_{6,12}=8 \cdot 2, P<0 \cdot 001$ ). However, these streams still had greatly reduced breakdown compared with the circumneutral streams (i.e. $8 \cdot 1 \pm 1 \cdot 3$ and $13 \cdot 4 \pm 1 \cdot 5$ times lower values in 1998-99 and 199798, respectively) and intermediate breakdown rates were consistently observed in MR.

\section{Discussion}

\section{EFFECT OF ACIDIFICATION ON LEAF BREAKDOWN}

Our results support the contention that stream acidification has a profound impact on litter breakdown, a key process in forested headwater streams. On average, breakdown was 10 times slower in the most acidified streams $(\mathrm{pH}<5 \cdot 0)$ compared with the sites of $\mathrm{pH}$ c. 7, which were similar (e.g. LM4 with $k=0.0055$ day $^{-1}$ ) to breakdown rates of beech litter in other unimpacted streams throughout Europe (0.0020-0.0058 day $^{-1}$, Pattee, Bornard \& Mourelatos 1986; 0.0024-0.0073 day $^{-1}$, Chauvet, Giani \& Gessner 1993; 0.0045 day ${ }^{-1}$, Gessner \& Chauvet 1994; 0.0060 day ${ }^{-1}$, Fleituch 2001).

Although water chemistry of the acidified streams in the Vosges Mountains was variable, PLS confirmed that $\mathrm{pH}$, alkalinity and total $\mathrm{Al}$ concentrations were the major variables explaining biological responses to acidification in freshwaters (cf. Townsend, Hildrew \& Francis 1983; Rutt, Weatherley \& Ormerod 1990; Rosemond et al. 1992), including ecosystem processes such as leaf breakdown. The effective prediction of breakdown rates by our regression model with only two variables, and the lack of confounding relationships with other chemical and/ or physical stream characteristics, suggests that the ultimate causes of reduced breakdown in acidified freshwaters might be simply related to stream water alkalinity and total Al concentration. Previous field observations suggested that differences in environmental factors other than $\mathrm{pH}$-related variables, particularly temperature and physical abrasion related to stream flow, were small and contributed only marginally to variations in leaf breakdown rate among streams (Dangles \& Guérold 2001b). 


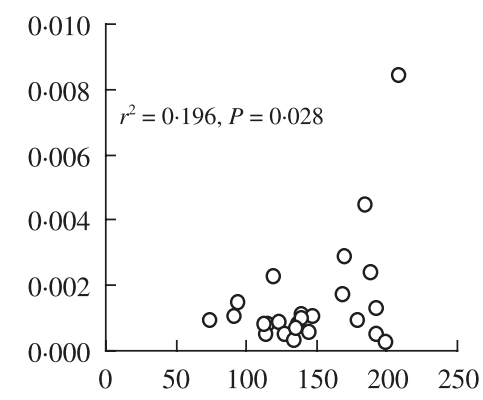

Fungal biomass $\left(\mu \mathrm{g}\right.$ ergosterol $\left.\mathrm{g}^{-1}\right)$
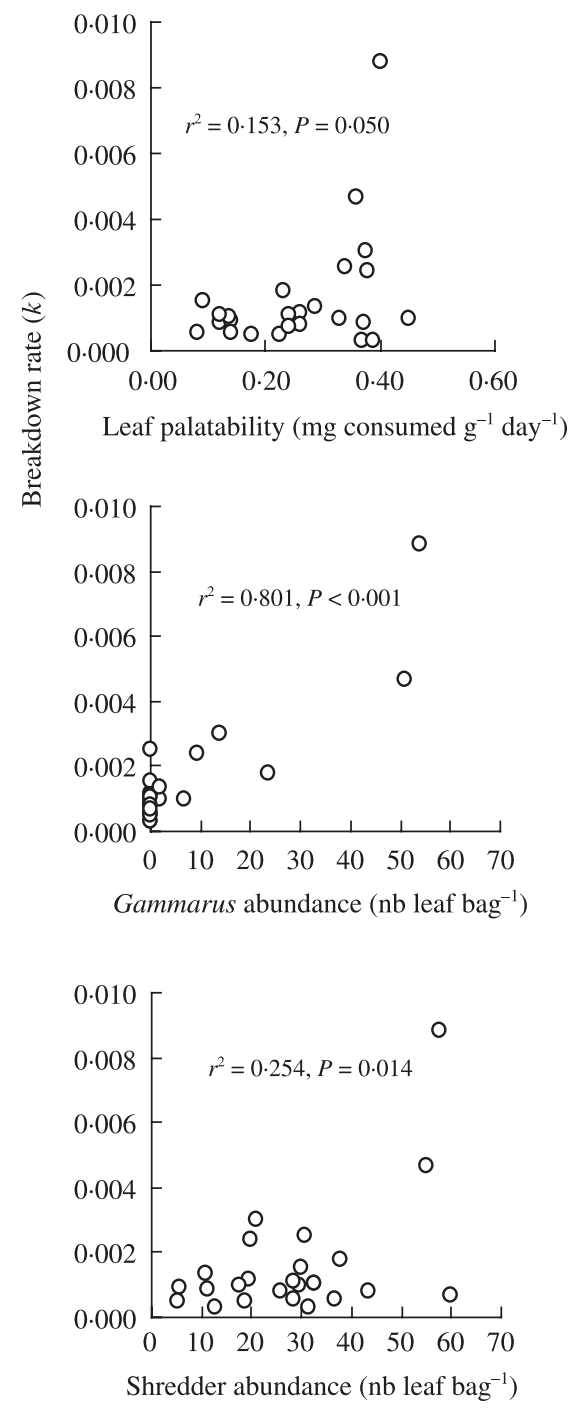

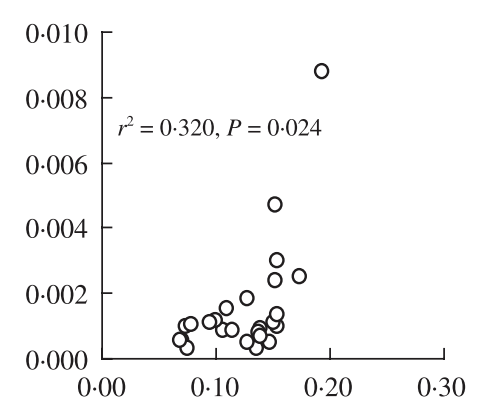

Microbial respiration $\left(\mathrm{mg} \mathrm{O}_{2} \mathrm{~g}^{-1}\right.$ day $\left.^{-1}\right)$
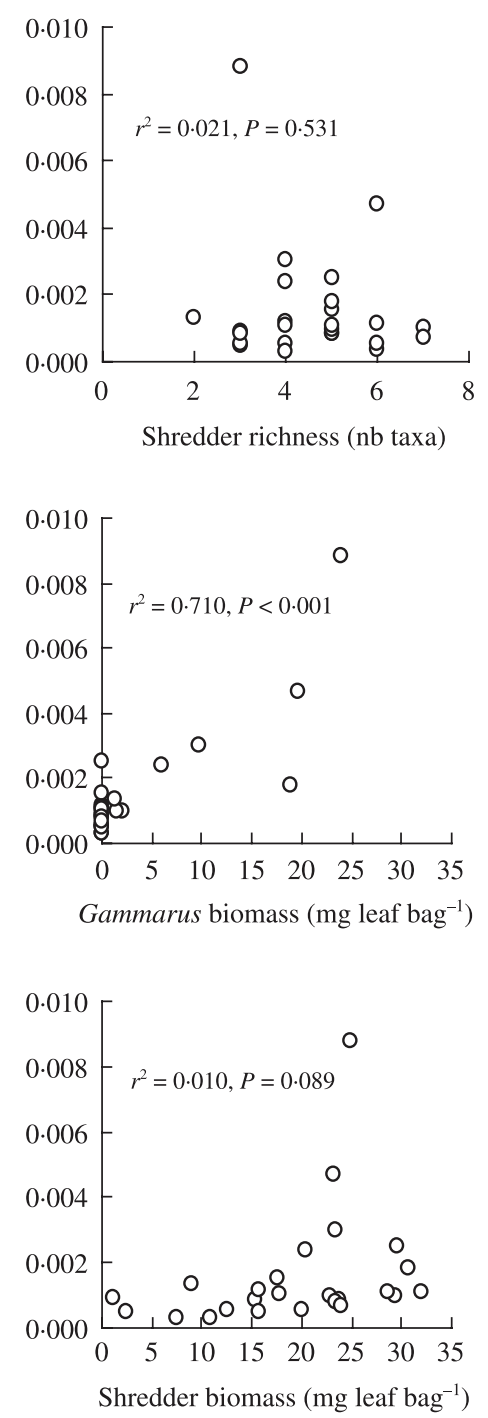

Fig. 5. Simple linear regressions of biological parameters vs. leaf breakdown rate calculated for the first 100 days of leaf breakdown in the streams. Biological variables likewise refer to values determined on leaves after 100 days of stream exposure. All values are means from three replicate leaf bags. $\mathrm{nb}=$ number.

In addition, our results indicate that the relation between acidification and leaf breakdown is incremental rather than showing an abrupt shift beyond a certain threshold. Although at variance with several studies conducted to establish critical limits of surface water acidification based on the response of invertebrates or fish (Fjellheim \& Raddum 1990; Lien et al. 1996), this finding is consistent with the pattern of litter breakdown found by Niyogi, Lewis \& McKnight (2001) in a series of streams affected by acid mine drainage.

\section{EVIDENCE FOR BIOLOGICAL MECHANISMS}

Evidence from various studies has indicated that acidification reduces leaf breakdown rates in streams (Mulholland et al. 1992; Meegan, Perry \& Perry 1996; 


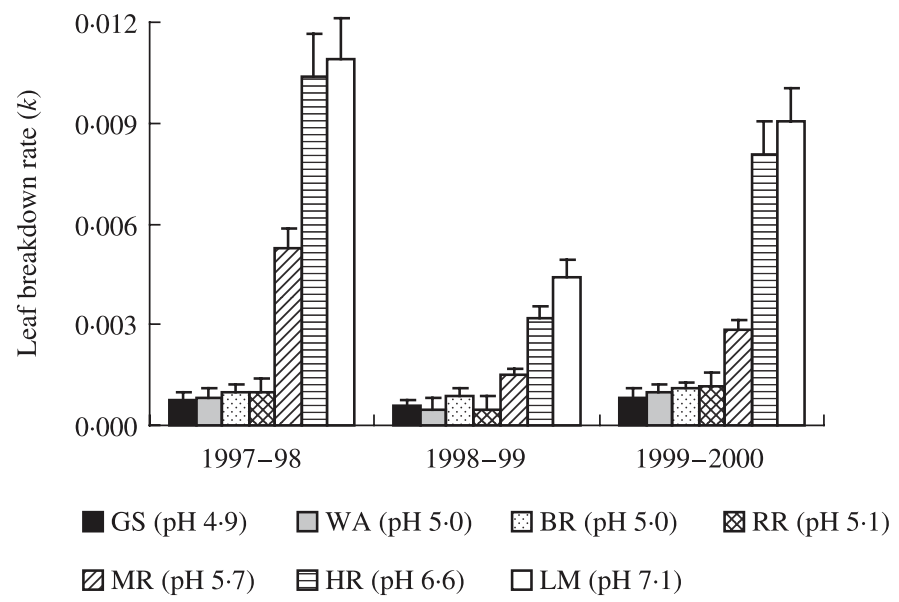

Fig. 6. Comparison of leaf breakdown rates at seven sites in the winter and spring of 1997-98, 1998-99 and 1999-2000. Bars indicate asymptotic standard errors. GS, WA, BR and RR are acidic streams; MR is slightly acidic; HR and LM are circumneutral sites. Values of stream $\mathrm{pH}$ are means of 28 measurements made over the 3 -year study period.

Dangles \& Guérold 1998). It has not been clear, however, whether the effect is mainly due to lower microbial activity or to changes in shredder communities (Maltby 1996). Our results indicate that the decrease in breakdown rates in acidified streams is mediated by both, as several microbial variables and leaf palatability were negatively related to stream acidity. Underlying mechanisms include elevated concentration of $\mathrm{H}$ and $\mathrm{Al}$ ions that affect ion regulation of shredders such as gammarids and trichopterans (Herrmann et al. 1993; Felten \& Guérold 2001). Calcium deficiency adds to the $\mathrm{pH}$ and Al stress, especially for gastropods and crustaceans (Rosemond et al. 1992), and calcium is also instrumental in the activity of fungal pectinases, a key enzyme in leaf degradation in streams (Suberkropp \& Klug 1980; Chamier \& Dixon 1982).

Rather than showing a gradual response, there appeared to be a threshold of fungal biomass, microbial respiration and leaf palatability below which litter breakdown was consistently low, whereas both low and high values were apparent above the threshold. Similarly, the relationship between breakdown rate and the total abundance or biomass of shredders was only weakly significant, with a threshold effect also noticeable. This lack of a significant relationship may be partly explained by the fact that nemouroid stoneflies (Leuctra, Protonemura and Nemoura; Zwick 2000) dominated the shredder assemblages in the acid streams. Previous studies have indicated that their role in leaf breakdown may be reduced in acidic conditions compared with circumneutral streams (Hieber \& Gessner 2002), especially when the shredders feed on recalcitrant leaves such as beech (Groom \& Hildrew 1989; Dangles \& Guérold 2001a,b; Dangles 2002).

A limited impact of nemouroid stoneflies on beech leaf breakdown in acidic conditions would also explain our observation that species richness of the shredder assemblages was unrelated to breakdown rate. This finding contrasts with laboratory feeding trials in which deliberate experimental manipulations of shredder richness enhanced leaf breakdown significantly (Jonsson \& Malmqvist 2000). Rather than species richness, the abundance and biomass of a single acid-sensitive species, G. fossarum, were good predictors of litter breakdown rate; G. fossarum was never observed in streams with a mean $\mathrm{pH}<6$ and their abundance and biomass explained $80 \%$ and $73 \%$, respectively, of the variation in breakdown among streams. Thus, differences in breakdown rates among streams appeared to be primarily related to the taxonomic composition of the shredder assemblages, specifically to the presence or absence of a single highly efficient shredder. Tests for effects of large shredders (including mainly large caddisflies in addition to G. fossarum) vs. small shredders (comprising primarily nemouroid stoneflies) did not reveal strong relationships with breakdown rate (simple linear regressions $P=0.33$ and $P=0 \cdot 26$, respectively). This result suggests that species identity (specifically the presence of $G$. fossarum) rather than a general species trait such as body size was the main determinant of litter breakdown rates across the acidity gradient. Gammarus fossarum may well be a key species in the functioning of the circumneutral beech forest streams we studied, not least because of its high abundance.

Even though biodiversity effects (Loreau et al. 2001) were not apparent in the present study, changes in shredder community structure through the loss of a key species caused by acidification had a profound effect on ecosystem functioning. Consequently, the specific sequence of species loss caused by environmental stressors must be taken into account when assessing the consequences of species losses resulting from environmental change (Jonsson et al. 2002).

Surface water acidification and recovery from acidification are temporal phenomena that may be only partly reflected by patterns observed across spatial gradients. In addition to the general quandary of basing causal inferences on correlations, this is a potential caveat 
of our approach to compare leaf breakdown rates across an acidity gradient if the aim is to make causal inferences about the effects of anthropogenic surface water acidification or recovery. The effect of lowered $\mathrm{pH}$ and increased $\mathrm{Al}$ concentrations could be tested with acid or Al-addition experiments in a set of currently still sufficiently buffered streams. Experimental simulation of the simultaneous loss of cations, however, is extremely difficult under field conditions. Consequently, even ecosystem-level acidification experiments (Hall et al. 1980; Brezonik et al. 1986; Ormerod et al. 1987) would represent at best only part of the acidification caused by air pollution. This limitation severely restricts the scope for inferences from such experimental results. Taking advantage of differences in stream water chemistry resulting from slight differences in bedrock composition within a region would thus seem to be a valuable, although not conclusive, approach for gaining insight into the mechanisms underlying the effects of stream acidification. As acidified streams recover, it will be possible to test experimentally the prediction derived from the present results: that poorly buffered streams when released from acidification stress show breakdown rates akin to those in circumneutral softwater streams with a higher buffering capacity. The predicted recovery of streams from acidification makes such examinations a real possibility.

\section{SYNTHESIS AND APPLICATIONS}

Despite marked reductions in atmospheric $\mathrm{S}$ deposition over the past 30 years, many streams remain acidified in several parts of the world (Likens, Driscoll \& Buso 1996; Arndt et al. 1997). With the naturally low buffering capacity of soils depleted of exchangeable cations, the expected recovery of stream water alkalinity following reduced acid loadings has been delayed in both North America and Europe (Probst et al. 1999; Stoddard et al. 1999). Liming might not offer a generally feasible symptomatic treatment because effective technical interventions are exceedingly costly (Bengtsson \& Bogelius 1995; Dickson \& Brodin 1995). Consequently, further reduction in acidifying emissions, especially $\mathrm{NO}_{\mathrm{x}}$, is urgently needed.

For effective and cost-efficient management, such efforts must go hand in hand with appropriate assessment. Networks measuring changes in air quality and atmospheric deposition, e.g. National Atmospheric Deposition Program (NADP) and Clean Air Status and Trends Network (CASTNet), are insufficient alone to assess acidification or recovery in aquatic ecosystems (Driscoll et al. 2001). Networks monitoring changes in water quality are currently rare, and networks assessing responses among biota are even more sparse (Driscoll et al. 2001). Exceptions are two long-term surveys conducted in Great Britain, which have shown only modest ecological response to both reduced acidifying emissions and liming (Lancaster et al. 1996; Bradley \& Ormerod 2002). Clearly, integrative, simple functional assessment methods, like that described here, would be an asset to such monitoring efforts.

Litter breakdown can clearly be a useful measure of ecosystem functioning in acid-sensitive headwaters. Despite notable among-year variation, possibly a large and rather constant reduction in breakdown rates (c. 90\%) was observed at the acidic sites in all years. Determining leaf breakdown rate and/or related variables may thus provide an effective, straightforward and relatively low-cost approach to stream assessment. Litter breakdown also allows the simultaneous evaluation of associated processes (e.g. microbial respiration) and patterns (e.g. shredder and fungal biomass and community composition) (Gessner \& Chauvet 2002). Such multiparameter approaches (Barbour, Stribling \& Karr 1995; Barbour 1997; Karr 1999) not only would facilitate the identification of mechanisms underlying changes in ecosystem functioning, but could augment routine biomonitoring of freshwaters impacted by a range of anthropogenic stressors.

\section{Acknowledgements}

This research was partly supported by a graduate Student Grant of the Lorraine Region to O. Dangles. Additional support was provided during the writing of this paper through a postdoctoral grant to O. Dangles from the European Science Foundation (LINKECOL Programme) at the University of Umeå, Sweden, and by the EU Commission (RivFunction; contract no. EVK1-CT-2001-00088) and the Swiss Federal Ministry of Education and Science (BBW no. 01.0087) to E. Chauvet and M. O. Gessner. Thanks to Vincent Felten, Guy Gehin, Michel Masson and Nathalie Masson for technical assistance in the field; Philippe Rousselle for his help with microbial respiration measurements; and Steve J. Ormerod and two anonymous referees for comments on earlier draft.

\section{References}

Abdi, H. (2003) Partial least squares. Encyclopedia of Social Sciences Methods (eds M. Lewis-Beck, A. Bryman \& T. Futing). Sage, Thousand Oaks, CA.

Arndt, R.L., Carmichael, G.R., Streets, D.G. \& Bhatti, N. (1997) Sulfur dioxide emissions and sectorial contributions to sulfur deposition in Asia. Atmosphere and Environment, 31, 1553-1572.

Barbour, M.T. (1997) The re-invention of biological assessment in the US. Human Ecological Risk Assessment, 3, 933-940.

Barbour, M.T., Stribling, J.B. \& Karr, J.R. (1995) Multimetric approach for establishing biocriteria and measuring biological condition. Biological Assessment and Criteria: Tools for Water Resource Planning and Decision Making (eds W.S. Davis \& T.P. Simon), pp. 63-77. Lewis Publishers, New York, NY. Bengtsson, B. \& Bogelius, A. (1995) Socio-economic consequences of aquatic liming. Liming of Acidified Surface Waters. A Swedish Synthesis (eds L. Henrickson \& Y.M. Brodin), pp. 423-455. Springer-Verlag, Berlin, Germany.

Boon, P.J. (2000) The development of integrated methods for assessing river conservation value. Hydrobiologia, 423, $413-428$. 
Bradley, D.C. \& Ormerod, S.J. (2002) Long-term effects of catchment liming on invertebrates in upland streams. Freshwater Biology, 47, 161-171.

Brezonik, P.L., Baker, L.A., Eaton, J., Frost, T., Garrison, P., Kratz, T., Magnuson, J., Perry, J., Rose, W., Shepard, B., Swenson, W., Watras, C. \& Webster, K. (1986) Experimental acidification of Little Rock Lake, Wisconsin. Water, Air, Soil Pollution, 30, 115-122.

Bunn, S.E. \& Davies, P.M. (2000) Biological processes in running waters and their implications for the assessment of ecological integrity. Hydrobiologia, 422, 61-70.

Bunn, S.E., Davies, P.M. \& Mosisch, T.D. (1999) Ecosystem measures of river health and their response to riparian and catchment degradation. Freshwater Biology, 41, 333-345.

Burton, T.M., Stanford, R.M. \& Allan, J.W. (1985) Acidification effects on stream biota and organic matter processing. Canadian Journal of Fisheries and Aquatic Sciences, 42, $669-675$.

Chamier, A.-C. (1987) Effect of $\mathrm{pH}$ on microbial degradation of leaf litter in seven streams of the English Lake District. Oecologia, 71, 491-500.

Chamier, A.-C. \& Dixon, P.A. (1982) Pectinases in leaf degradation by aquatic hyphomycetes: the enzyme and leaf maceration. Journal of General Microbiology, 128, 24692483.

Chauvet, E., Giani, N. \& Gessner, M.O. (1993) Breakdown and invertebrate colonization of leaf litter in two contrasting streams: the significance of Oligochaeta in a large river. Canadian Journal of Fisheries and Aquatic Sciences, 50, 488-495.

Dambrine, E., Pollier, B., Poswa, A., Ranger, J., Probst, A., Viville, D., Biron, P. \& Granier, A. (1998) Evidence of current acidification in spruce stands in the Vosges Mountains, northeastern France. Water, Air and Soil Pollution, 105, 43-52.

Dambrine, E., Ulrich, E., Cenac, P., Durand, P., Gauquelin, T., Mirabel, P., Nys, C., Probst, A., Ranger, J. \& Zephoris, M. (1995) Atmospheric deposition in France and possible relation with forest decline. Forest Decline and Atmospheric Deposition Effects in the French Mountains (eds G. Landmann \& M. Bonneau), pp. 177-200. Springer Verlag, Berlin, Germany.

Dangles, O. (2002) Functional plasticity of benthic macroinvertebrates: implication for trophic dynamics in acid streams. Canadian Journal of Fisheries and Aquatic Sciences, 59, 1563-1573.

Dangles, O. \& Guérold, F. (1998) A comparative study of beech leaf breakdown, energetic content, and associated fauna in acidic and non-acidic streams. Archiv für Hydrobiologie, 144, 25-39.

Dangles, O. \& Guérold, F. (2001a) Influence of shredders in mediating breakdown rates of beech leaves in circumneutral and acidic forest streams. Archiv für Hydrobiologie, 151, 649-666.

Dangles, O. \& Guérold, F. (2001b) Linking shredders and leaf litter processing: insights from an acidic stream study. International Review of Hydrobiology, 86, 395-406.

Dickson, W. \& Brodin, Y.W. (1995) Strategies and methods for freshwater liming. Liming of Acidified Surface Waters. A Swedish Synthesis (eds L. Henrickson \& Y.M. Brodin), pp. 81-116. Springer-Verlag, Berlin, Germany.

Driscoll, C.T., Lawrence, G.B., Bulger, A.J., Butler, T.J., Cronan, C.S., Eagar, C., Lambert, K.F., Likens, G.E., Stoddard, J.L. \& Weathers, K.C. (2001) Acidic deposition in the northeastern United States: sources and inputs, ecosystem effects, and management strategies. Bioscience, 51, 180-198

EU (2000) Directive 2000/60/EC of the European Parliament and of the Council of 23 October 2000: Establishing a Framework for Community Action in the Field of Water Policy. The European Parliament, Brussels, Belgium.
Felten, V. \& Guérold, F. (2001) Hyperventilation and loss of hemolymph $\mathrm{Na}^{+}$and $\mathrm{Cl}^{-}$in the freshwater amphipod Gammarus fossarum exposed to acid stress: a preliminary study. Diseases of Aquatic Organisms, 45, 77-80.

Fjellheim, A. \& Raddum, G.G. (1990) Acid precipitation: biological monitoring of streams and lakes. Science of the Total Environment, 96, 57-66.

Fleituch, T. (2001) Beech leaf breakdown and POM storage along an altitudinal stream gradient. International Review of Hydrobiology, 86, 515-525.

Gessner, M.O. \& Chauvet, E. (1994) Importance of stream microfungi in controlling breakdown rates of leaf litter. Ecology, 75, 1807-1817.

Gessner, M.O. \& Chauvet, E. (2002) A case for using litter breakdown to assess functional stream integrity. Ecological Applications, 12, 498-510.

Gessner, M.O., Chauvet, E. \& Dobson, M. (1999) A perspective on leaf litter breakdown in streams. Oikos, $\mathbf{8 5}$, $377-384$.

Gessner, M.O. \& Newell, S.Y. (2002) Biomass, growth rate, and production of filamentous fungi in plant litter. Manual of Environmental Microbiology, 2nd edn (eds C.J. Hurst, R.L. Crawford, G.R. Knudsen, M.J. McInerney \& L.D. Stetzenbach), pp. 390-408. ASM Press, Washington, DC.

Gessner, M.O. \& Schmitt, A. (1996) Use of solid-phase extraction to determine ergosterol concentrations in plant tissue colonized by fungi. Applied and Environmental Microbiology, 62, 415-419.

Gessner, M.O. \& Schwoerbel, J. (1989) Leaching kinetics of fresh leaf-litter with implications for the current concept of leaf-processing in streams. Archiv für Hydrobiologie, 115, 81-90.

Giller, P. \& Malmqvist, B. (1998) The Biology of Rivers and Streams. Oxford University Press, Oxford, UK.

Graça, M.A.S. (2001) The role of invertebrates on leaf litter decomposition in streams: a review. International Review of Hydrobiology, 86, 383-396.

Gran, G. (1952) Determination of the equivalence point in potentiometric titrations. Analyst of London, 77, 661-671.

Griffith, M.B. \& Perry, S.A. (1993) Colonization and processing of leaf litter by macroinvertebrate shredders in streams of contrasting pH. Freshwater Biology, 30, 93-103.

Groom, A.P. \& Hildrew, A.G. (1989) Food quality for detritivores in streams of contrasting pH. Journal of Animal Ecology, 58, 863-881.

Guérold, F., Boudot, J.P., Merlet, D., Rouillet, J., Vein, D. \& Jacquemin, G. (1997) Evaluation de l'état d'acidification des cours d'eau du département des Vosges. Technical Report No. 14/95C. Conseil Général Des Vosges, Metz, France.

Hall, R.J., Likens, G.E., Fiance, S.B. \& Hendrey, G.R. (1980) Experimental acidification of a stream in the Hubbard brook experimental forest, New Hampshire. Ecology, 61, 976-989.

Hämäläinen, H. \& Huttunen, P. (1996) Inferring the minimum $\mathrm{pH}$ of streams from macroinvertebrates using weighted averaging regression and calibration. Freshwater Biology, 36, 697-709.

Herrmann, J., Degerman, E., Gerhardt, A., Johansson, C., Lingdell, P.E. \& Munitz, I.P. (1993) Acid-stress effects on stream biology. Ambio, 22, 298-307.

Hieber, M. \& Gessner, M.O. (2002) Contribution of stream detritivores, fungi, and bacteria to leaf breakdown based on biomass determinations. Ecology, 83, 1026-1038.

Hooper, D., Solan, M., Symstad, A., Díaz, S., Gessner, M.O., Buchmann, N., Dégrange, V., Grime, P., Hulot, F., MermillodBlondin, F., Roy, J., Spehn, E. \& van Peer, L. (2002) Species diversity, functional diversity and ecosystem functioning. Biodiversity and Ecosystem Functioning: Synthesis and Perspectives (eds M. Loreau, S. Naeem \& P. Inchausti), pp. 195-208. Oxford University Press, Oxford, UK. 
Jonsson, M. \& Malmqvist, B. (2000) Ecosystem process rate increases with animal richness: evidence from leaf eating aquatic insects. Oikos, 89, 519-523.

Jonsson, M., Dangles, O., Malmqvist, B. \& Guérold, F. (2002) Simulating species loss following disturbance: assessing the effects on process rates. Proceedings of the Royal Society of London, 269, 1047-1052.

Karr, J.R. (1999) Defining and measuring river health. Freshwater Biology, 41, 221-234.

Lancaster, J., Real, M., Juggins, S., Monteith, D.T., Flower, R.J. \& Beaumont, W.R.C. (1996) Monitoring temporal changes in the biology of acid waters. Freshwater Biology, 36, 179-201.

Larsen, J., Birks, H.J.B., Raddum, G.G. \& Fjellheim, A. (1996) Quantitative relationships of invertebrates to $\mathrm{pH}$ in Norwegian river systems. Hydrobiologia, 328, 57-74

Lawrence, G.B., David, M.B., Lovett, G.M., Murdoch, P.S., Burns, D.A., Baldigo, B.P., Thompson, A.W., Porter, J.H. \& Stoddard, J.L. (1999) Soil calcium status and the response of stream chemistry to changing acidic deposition rates in the Catskill Mountains of New York. Ecological Applications, 9, 1059-1072

Lepori, F., Barbieri, A. \& Ormerod, S.J. (2003a) Causes of episodic acidification in Alpine streams. Freshwater Biology, 48, 175-189.

Lepori, F., Barbieri, A. \& Ormerod, S.J. (2003b) Effects of episodic acidification on macroinvertebrate assemblages in Swiss Alpine streams. Freshwater Biology, 48, 18731885.

Lien, L., Raddum, G.G., Fjellheim, A. \& Henriksen, A. (1996) A critical limit for acid neutralizing capacity in Norwegian surface waters, based on new analyses of fish and invertebrate response. Science of the Total Environment, 177, 173-193.

Likens, G.E., Butker, T.J. \& Buso, D.C. (2001) Long- and short-term changes in sulphate deposition: effects of the 1990 Clean Air Act Amendments. Biogeochemistry, 52, $1-11$.

Likens, G.E., Driscoll, C.T. \& Buso, D.C. (1996) Long-term effects of acid rain: response and recovery of a forest ecosystem. Science, 272, 244-246.

Loreau, M., Naeem, S., Inchausti, P., Bengtsson, J., Grime, J.P., Hector, A., Hooper, D.U., Huston, M.A., Raffaelli, D., Schmid, B., Tilman, D. \& Wardle, D.A. (2001) Biodiversity and ecosystem functioning: current knowledge and future challenges. Science, 294, 804-809.

Maltby, L. (1996) Detritus processing. River Biota: Diversity and Dynamics (eds G. Petts \& P. Calow), pp. 145-167. Blackwell Science, Oxford, UK.

Maltby, L., Boxall, A.B.A., Forrow, D.M., Calow, P. \& Betton, C.I. (1995) The effects of motorway runoff on freshwater ecosystems. I. Field study. Environmental Toxicology and Chemistry, 14, 1079-1092.

Meegan, S.K., Perry, S.A. \& Perry, W.B. (1996) Detrital processing in streams exposed to acidic precipitation in the Central Appalachian Mountains. Hydrobiologia, 339, $101-110$.

Minshall, G.W. (1996) Bringing biology back into water quality assessments. Freshwater Ecosystems: Revitalizing Educational Programs in Limnology (ed. Committee on Inland Aquatic Ecosystems), pp. 289-324. Water Science and Technology Board, Commission on Geosciences, National Research Council, Washington, DC, USA.

Mulholland, P.J., Driscoll, C.T., Elwood, J.W., Osgood, M.P., Palumbo, A.V., Rosemond, A.D., Smith, M.E. \& Schofield, C. (1992) Relationship between stream acidity and bacteria, macroinvertebrates and fish: a comparison of north temperate and south temperate mountain streams, USA. Hydrobiologia, 239, 7-24.

Nelson, S.M. (2000) Leaf pack breakdown and macroinvertebrate colonization: bioassessment tools for a highaltitude regulated system? Environmental Pollution, 110, $321-329$.
Niyogi, D.K., Lewis, W.M. \& McKnight, D.M. (2001) Litter breakdown in mountain streams affected by mine drainage: biotic mediation of abiotic controls. Ecological Applications, 11, 506-516.

Ormerod, S.J., Boole, P., McCahon, C.P., Weatherley, N.S., Pascoe, D. \& Edwards, R.W. (1987) Short-term experimental acidification of a Welsh stream: comparing the biological effects of hydrogen ions and aluminium. Freshwater Biology, 17, 341-356.

Otto, C. \& Svensson, B.S. (1983) Properties of acid brown water streams in south Sweden. Archiv für Hydrobiologie, 99, 5-36.

Pattee, E., Bornard, C. \& Mourelatos, S. (1986) La décomposition des feuilles mortes dans le réseau fluvial du Rhône: influence du milieu et principaux agents responsables. Revue des Sciences de l'Eau, 5, 45-74.

Petersen, R.C. \& Cummins, K.W. (1974) Leaf processing in a woodland stream. Freshwater Biology, 4, 343-368.

Probst, A., Dambrine, E., Viville, D. \& Fritz, B. (1990a) Influence of acid atmospheric inputs on surface water chemistry and mineral fluxes in a declining spruce stand within a small granitic catchment (Vosges Massif, France). Journal of Hydrology, 116, 101-124.

Probst, A., Massabuau, J.C., Probst, J.L. \& Fritz, B. (1990b) Acidification des eaux de surface sous l'influence des précipitations acides: rôle de la végétation et du substratum, conséquence pour les populations de truites. Le cas des ruisseaux des Vosges. Compte Rendu de l'Académie des Sciences de Paris, 311, 405-411.

Probst, A., Party, J.P., Février, C., Dambrine, E., Thomas, A.L. \& Stussi, J.M. (1999) Evidence of springwater acidification in the Vosges Mountains (N-E France): influence of bedrock buffering capacity. Water, Air, and Soil Pollution, 114, 395-411.

Rosemond, A.D., Reice, S.R., Elwood, J.W. \& Mulholland, P.J. (1992) The effects of stream acidity on benthic invertebrate communities in the south-eastern United States. Freshwater Biology, 27, 193-209.

Rutt, G.P., Weatherley, N.S. \& Ormerod, S.J. (1990) Relationship between the physicochemistry and macroinvertebrates of British upland streams: the development of modelling and indicator systems for predicting fauna and detecting acidity. Freshwater Biology, 24, 463-480.

Schindler, D.W. (1988) Effects of acid-rain on freshwater ecosystems. Science, 239, 149-157.

Schindler, D.W., Curtis, P.J., Parker, B.R. \& Stainton, M.P. (1996) Consequences of climate warming and lake acidification for UV-B penetration in North American boreal lakes. Nature, 379, 705-708.

Statzner, B., Bis, B., Dolédec, S. \& Usseglio-Polatera, P. (2001) Perspectives for biomonitoring at large spatial scales: a unified measure for the functional composition on invertebrate communities in European running waters. Basic and Applied Ecology, 2, 73-85.

Stoddard, J.L., Jeffries, D.S., Lükeviler, A., Clair, T.A., Dillon, P.J., Driscoll, C.T., Forsius, M., Johannessen, M., Kahl, J.S., Kellogg, J.H., Kemp, A., Mannio, J., Monteith, D., Murdoch, P.S., Patrick, S., Rebsdorf, A., Skjelkvale, B.L., Stainton, M.P., Traaen, T., Van Dom, H., Webster, K.E., Wieting, J. \& Wilander, A. (1999) Regional trends in aquatic recovery from acidification in North America and Europe. Nature, 401, 575-578.

Suberkropp, K. \& Klug, J.M. (1980) The maceration of deciduous leaf litter by aquatic hyphomycetes. Canadian Journal of Botany, 58, 1025-1031.

Sullivan, T.J., Eilers, J.M., Cosby, B.J. \& Vache, K.B. (1997) Increasing role of nitrogen in the acidification of surface waters in the Adirondack Mountains, New York. Water, Air and Soil Pollution, 95, 313-336.

Tachet, H., Bournaud, M., Richoux, P. \& Usseglio-Polatera, P. (2000) Invertébrés d'eau douce. Systématique, Biologie, Ecologie. CNRS Publishers, Paris, France. 
Thioulouse, J., Chessel, D., Dolédec, S. \& Olivier, J.M. (1997) ADE-4: a multivariate analysis and graphical display software. Statistics and Computing, 7, 75-83.

Townsend, C.R., Hildrew, A.G. \& Francis, J.E. (1983) Community structure in some southern English streams: the influence of physicochemical factors. Freshwater Biology, 13, $521-544$.

Wallace, J.B. \& Webster, J.R. (1996) The role of macroinvertebrates in stream function. Annual Review of Entomology, 41, 115-139.

Wallace, J.B., Eggert, S.L., Meyer, J.L. \& Webster, J.R. (1997) Multiple trophic levels of a forest stream linked to terrestrial litter inputs. Science, 277, 102-104.
Wallace, J.B., Eggert, S.L., Meyer, J.L. \& Webster, J.R. (1999) Effects of resource limitation on a detrital-based ecosystem. Ecological Monographs, 69, 409-442.

Wallace, J.B., Grubaugh, J.W. \& Whiles, M.R. (1996) Biotic indices and stream ecosystem processes: results from an experimental study. Ecological Applications, 6, 140-151.

Webster, J.R. \& Benfield, E.F. (1986) Vascular plant breakdown in freshwater ecosystems. Annual Review of Ecology and Systematics, 17, 567-594.

Zwick, P. (2000) Phylogenetic system and zoogeography of the Plecoptera. Annual Review of Entomology, 45, 709-746. 